\title{
THE EFFECT OF BUDGET REFOCUSING DURING THE COVID-19 PANDEMIC ON THE REALIZATION OF THE APBD IN CENTRAL JAVA PROVINCE
}

\author{
Aerona Khatulistiwa ${ }^{1}$ \\ Universitas Tidar \\ E-mail: ${ }^{1)}$ aeronakhat@gmail.com
}

\begin{abstract}
At the beginning of March 2020 there was a Covid-19 pandemic that hit Indonesia which eventually gave rise to several social restrictions policies for the community. In this case, several financial sectors are affected by the policy. In the context of handling the Covid-19 pandemic, there must be a budget refocusing or reallocation focused on handling Covid-19 in Indonesia. However, the refocusing effort that has been carried out in a short time has resulted in problems that have an impact on the realization of the reallocated budget (before the pandemic). In this regard, a government regulation policy in lieu of the Law is formed and issued which is the basis for the replacement of the Law on Regional Government. In this study, the researcher uses a qualitative descriptive method, which is a non-quantitative data collection and analysis method with the aim of exploring social relationships and a description of the reality experienced by the response, or what is commonly referred to as the problem formulation to be used to explore in depth research. The locus of this research is in Central Java Province, using secondary data sourced from several literature studies.
\end{abstract}

Keywords: Refocusing, Pandemic, Realization, Regional Revenue and Expenditure Budget (APBD), Central Java Province

\section{INTRODUCTION}

The Covid-19 pandemic has had such a major impact on the slowing down of national economic growth, a decrease in state revenues, and an increase in state spending, financing, and society at large, so that various government efforts are needed to save health and the national economy, according to presidential instructions number 4 of 2020 focus on spending on health, social safety nets, and economic recovery, including the business world and affected communities. To immediately refocus activities and reallocate the budget through the budget revision mechanism and immediately submit proposals and budget revisions to the Minister of Finance in accordance with their authority and in the regulations of the Ministry of Home Affairs (Kemendagri) and the Ministry of Finance (Kemenkeu) on April 9, 2020 issued a Joint Decree No. 177/KMK/07/2020 regarding the refocusing of the 2020 APBD (Regional Revenue and Expenditure Budget) to accelerate the handling of the Covid19 outbreak.

Which then instructs every Provincial/Regency/City Government to submit a 2020 budget (APBD) adjustment report no later than 23 April 2020, however, data as of 23 April shows that there are 13 Local Governments that have not reported 2020 Budget Refocusing. Furthermore, according to data in May, the nominal collected from the reallocation of the APBD amounted to Rp. 66.38 trillion from the outlook of the Ministry of Finance which 
projects that the APBD that can be reallocated for handling COVID-19 could reach Rp. 94.39 trillion. Hence, it can be said that there are problems with the local government (Pemda) in refocusing the budget (Haikal, 2021).

Then after the refocusing is carried out, each region is obliged to realize the budget in order to accelerate the handling of the Covid-19 pandemic as well, including also carrying out its obligations to be able to channel funds for the operation of government and public welfare, but during the pandemic, especially after a budget refocusing, there is a change in priorities and urgency in the use of the budget as a result, hence this issue needs to be studied more deeply so that it is known that refocusing affects the realization of the APBD, which can then be seen the problems or obstacles that occur in it, so that solutions or alternatives can also be found to resolve the problem.

\section{LITERATURE REVIEW}

\subsection{Local Budgeting Theory}

In the Government Regulation of the Republic of Indonesia Number 12 of 2019 concerning Regional Financial Management it is stated that what is meant by Regional Finance is all the rights and obligations of the Region in the context of administering Regional Government which can be valued in money as well as all forms of wealth that can be used as the property of the Region in connection with the rights and obligations the area. Meanwhile, what is meant by Regional Financial Management is all activities that include planning, budgeting, implementation, administration, reporting, accountability, and supervision of Regional Finances (Karjoko et al., 2020).

According to Pekei (in (Barbakem et al., 2018)), the government budget or State Revenue and Expenditure Budget (APBN) and Regional Revenue and Expenditure Budget (APBD) are managed by the government, therefore the budget is a statement about the estimated performance to be achieved during a certain period stated in financial or monetary terms. In the process of budgeting is called budgeting, the budgeting must be prepared based on the interests of public sector organizations, in the preparation of the budget by the government is a fairly broad stage because it does not only consider the economy but also the socio-political factors that are increasingly thick in community organizations.

Budgeting at the government is related to determining the amount of fund allocation for each program or activity to be carried out in one monetary unit, hence there are several aspects that must be met in the preparation of the government budget, namely planning, controlling, and aspects of transparency and accountability in general. In the preparation of the government budget, there are several principles of the government budget, including the control of authority by the legislature, namely that the budget must obtain prior approval by the legislature before the budget is spent by the government/executives and is transparent and open where the budget is prepared openly or transparently and can be easily identified by public.

\subsection{Budget Refocusing}

Refocusing Budget Refocusing is an alternative in minimizing the occurrence of an economic recession in order to ensure national economic stability. Refocusing can be used by a country to ensure financial stability due to the global economic shock and make the economic system decline due to inappropriate circumstances or experiencing a crisis (Junaidi 


\section{JOURNAL OF MANAGEMENT, ACCOUNTING, GENERAL FINANCE AND INTERNATIONAL ECONOMIC ISSUES (MARGINAL) \\ VOLUME 1 ISSUE 1 (2021)}

et al., 2020). Further, Weston et al. (1994) also argue that refocusing will make it easier for a manager to monitor and make wiser decisions when the company's business is in a slump. Meanwhile, this also can be happening in a country, the concept of refocusing should also be applied to guaranteeing a country's financial stability, especially when facing a slump/crisis. In the aspect of budget policy, special rules governing refocusing are regulated by the government through Presidential Instruction Number 4 of 2020 concerning Refocusing Activities, Budget Reallocation, and Procurement of Goods and Services in the Context of Accelerating the Handling of COVID-19.

Refocusing is also an alternative to minimize the occurrence of an economic recession in order to ensure the stabilization of national/country economists. In the consideration of refocusing, of course, there will be a global economic crash due to a thing or event that weakens the economic systematization caused by the impact of inappropriate or not strategic policies (Kartika, 2021).

In fact, the prevention and control process (Covid-19) must be placed at the top priority in all government policies.50 The presence of the Joint Decree of the Minister of Home Affairs and the Minister of Finance of the Republic of Indonesia Number 119/2814/SJ Number $177 / \mathrm{KMK} / 07 / 2020$ provides several provisions Important aspects of efforts to accelerate the handling of (Covid-19) related to the use of the APBD include the following:

1) Requires regional heads to make adjustments to regional revenue targets in the APBD through 2 (two) ways: First, adjustment of transfer income to regions and village funds (TKDD). Second, the adjustment of local revenue.

2) Regional heads must make adjustments to regional spending in the context of preventing and handling the pandemic (Covid-19), consisting of: (1) spending on health, such as the procurement of personal protective equipment (PPE) for medical personnel as well as the provision of service facilities and equipment to the community and patient care. (2) Provision of a social safety net, such as the provision of social assistance to underprivileged communities. (3) Handling economic impacts.

3) Regional heads must prioritize the use of budgets and methods of implementing activities and budgets through reallocating the use of honorarium budgets, social assistance, and grants to then be transferred to social assistance budgets for the poor who have decreased purchasing power due to the pandemic (Covid-19) (Juliasari \& Rizal, 2021).

\section{RESEARCH METHOD}

This research is descriptive qualitative research, which is a non-quantitative method of collecting and analyzing data with the aim of exploring social relationships and a description of the reality experienced by the response (Saraclaers, 1993 in (Akbar, 2018)), or commonly referred to as the formulation of the problem to be used by researchers to explore what is being studied in depth. The locus of this research is in Central Java Province, using secondary data sourced from several literature studies. The qualitative analysis carried out by the researchers is expected to find the results of a comprehensive study. 


\section{RESULT AND DISCUSSION}

The outbreak of the Covid-19 case in Indonesia affects all sectors, especially in the social and economic fields. Seeing these conditions, the President has instructed all Ministries/Institutions (K/L) and regions to refocus the budget for health funds, social assistance (bansos) and support the business world, especially MSMEs. The central government through the Ministry of Finance of the Republic of Indonesia, issued a policy to deal with Covid-19 by mobilizing resources from the financial side to support the handling of Covid-19. In this case, the Ministry of Finance has made regulations that encourage Regional Governments to refocus their budgets for the purpose of handling Covid-19.

All forms of activity can have an impact or consequence that must be faced. This is also inseparable from the policy. Therefore, refocusing the budget will also give rise to various types of perspectives from the impact, including the example that the previous budgeting certainly could not be carried out properly.

Budget refocusing and reallocation have an impact on various sectors, especially the achievement of development targets in 2020. Refocusing and reallocating the budget are aimed at accelerating the handling of Covid-19. The impact of the Covid-19 pandemic has resulted in the set targets being constrained.

Table 1 Budget Plan and Budget Realization

\begin{tabular}{|c|c|c|c|c|c|}
\hline \multirow{2}{*}{ No } & \multirow{2}{*}{ Description } & \multicolumn{2}{|l|}{2020} & \multirow{2}{*}{$\%$} & \multirow{2}{*}{2019} \\
\hline & & Budget & Realisation & & \\
\hline 1 & 2 & 3 & 4 & $5=(4 / 3)$ & 4 \\
\hline \multirow{7}{*}{$\begin{array}{l}3 \\
4\end{array}$} & Income & $26.255 .251 .903 .000,00$ & $25.393 .735 .934 .148,00$ & 96,72 & $25.859 .780 .137 .936,00$ \\
\hline & Expenditure and Transfer & 27.374.409.350.000,00 & $25.651 .740 .349 .991,00$ & 93,71 & $26.151 .062 .842 .457,0 \mathrm{C}$ \\
\hline & Surplus (Deficit) & $(1.119 .157 .447 .000,00)$ & $(258.004 .415 .843,00)$ & - & $(291.282 .704 .521,00)$ \\
\hline & Financing & & & & \\
\hline & - Receipts & $1.119 .157 .447 .000,00$ & $1.119 .348 .228 .370,00$ & 100,02 & $1.630 .776 .601 .765,0 \mathrm{C}$ \\
\hline & - Expenditures & - & - & - & $220.336 .450 .544,0 \mathrm{C}$ \\
\hline & NET Financing & 1.119.157.447.000,00 & $1.119 .348 .228 .370,00$ & & $1.410 .440 .151 .221,0 \mathrm{C}$ \\
\hline 5 & Excess of Budget Calculation (SLLPA) & . & $861.343 .812 .527,00$ & . & $1.119 .157 .446 .700,00$ \\
\hline
\end{tabular}

Based on the table above, there is a gap between the budget plan and budget realization, in the income description there is a 2020 budget plan of Rp. 26.255.251.903.000,00 and what was realized from the budget was Rp. 25.393.735.934.148,00, which means $96.72 \%$ realized, as a comparison in 2019 which was realized at Rp. 25.859.780.137.936,00, which means a decrease in income from the previous year. While in the description of expenditures and transfers there is a budget plan of Rp. 27.374.409.350.000,00 and what was realized from the budget was Rp. 25.651.740.349.991,00, which means that $93.71 \%$ was realized, as a comparison in 2019 which was realized at Rp. 26.151.062.842.457,00.

Moreover, the problems faced in managing revenue for Fiscal Year 2020 are as follows: 


\section{JOURNAL OF MANAGEMENT, ACCOUNTING, GENERAL FINANCE AND INTERNATIONAL ECONOMIC ISSUES (MARGINAL) \\ VOLUME 1 ISSUE 1 (2021)}

1) The Covid-19 pandemic period has affected the economic level of the community which has an impact on motor vehicle tax receipts, during the pandemic direct billing activities (door to door) and joint raids with the police are not possible.

2) The Covid-19 pandemic period affected the economic level of the community which resulted in a decline in people's purchasing power for new vehicles, thus affecting the acceptance of the Transfer of Names Fee. According to Gaikindo and AISI Letters, that there was a decrease in the vehicle sales target of $40 \%$,

3) With many restrictions on people's mobility, causing fuel consumption to decline and resulting in a decrease in PBBKB revenues,

4) Not yet optimal level of taxpayer compliance to pay taxes on time,

5) Not yet optimal on the use and utilization of regional assets.

Meanwhile, in the implementation and management of regional expenditures, there are still obstacles and problems, namely as follows:

1) The understanding of SKPD financial managers, especially UPT/Balai, is not yet optimal on the integrated regional financial information system;

2) Not yet optimal regarding the use of Cash Management System (CMS) by financial managers of SKPD/UPT/Balai/Satker, especially in interbank services and tax payments as well as infrastructure that has not yet reached remote areas;

3) There are auction failures and delays in the implementation of district/city Financial Aid activities;

4) Lack of understanding of financial management and goods, especially in Secondary Education Units (SMA/SMK) and Special Education Units (SLB) on the mechanism for accountability for school finances and regional property that applies to SMA/SMK/SLB.

5) There is a new regulation Government Regulation Number 12 of 2019 concerning Regional Financial Management as a replacement for Government Regulation Number 58 of 2005 concerning Regional Financial Management.

\section{CONCLUSION}

Based on these conditions, the researcher can conclude that the central government's policy on APBD reallocation is ineffective, given the number of regional governments that are still constrained and ineffective in carrying out APBD reallocation, owing to too few deadlines or can be said to be tight, as well as many aspects that must be adjusted on the APBD reallocation report. As a consequence, when managing state finances, particularly budget reallocation, it is critical to actively cooperate between the center and the regions to avoid mistakes. Budgeting measures in regions during the Covid-19 pandemic must, of course, be based on needs in order to expedite management from the health, political, and economic perspectives, as well as those related to community interests. This enables the truth to become the foundation for the emergence of Presidential Instruction Number 4 of 2020 about Refocusing Activities, Reallocation of Budgets, and Procurement of Goods and Services in the Context of Accelerating Covid-19 Handling. However, the potential for deviations from regional financial policy from budget refocusing is very clear, notably by putting the regional head or executive organ in charge of budgeting and budget execution 
difficulties. Whereas in the Republic of Indonesia's Constitution, what is meant by regional budgeting must be defined by the executive and legislative branches. This is where the Presidential Instruction on Regional Budget Refocusing should be updated with a Government Regulation rather than a Presidential Instruction.

\section{Suggestion}

The results of the research presented by the researcher managed to find some suggestions that are possible to be used by several entities or governments as well, here are some suggestions from the researcher:

1) Organizing technical guidance to financial managers up to the UPT/Balai and PPKSKPD levels as well as improving the Integrated Regional Financial Information System;

2) The deadline is too short and there are many aspects that must be adjusted in the APBD reallocation report. Therefore, in the management of state finances, in particular the reallocation of the budget, it is necessary to actively coordinate between the centre and the regions to avoid the mistakes;

3) Perform integration of regional financial management applications with the Cash Management System and Padak applications as well as integrate regional financial management applications with Cash Management System applications and tax applications as well as encourage Central Java Bank to improve services to remote areas;

4) Carry out monitoring to accelerate the implementation of Financial Aid activities to districts/cities;

5) Prepare regulations governing the management of finances and school property and Technical Guidance on reporting school finances and regional property that apply to SMA/SMK/SLB;

6) Socialization of Government Regulation Number 12 of 2019 concerning Regional Financial Management to financial managers in SKPD and Regency/City, as well as making adjustments to regional financial management regulations

\section{REFERENCES}

Akbar, I. (2018). Perencanaan Partisipatif Dalam Pembangunan Lokal: Studi Di Kota Bandung. Jurnal Reformasi Administrasi: Jurnal Ilmiah Untuk Mewujudkan Masyarakat Madani, 5(2), 101-108.

Barbakem, D. I., Tinangon, J. J., \& Sabijono, H. (2018). Analisis Perencanaan Dan Penganggaran Untuk Anggaran Pendapatan Dan Belanja Daerah Pada Badan Keuangan Kabupaten Kepulauan Sangihe Tahun Anggaran 2015. Going Concern: Jurnal Riset Akuntansi, 13(01).

Haikal, M. F. F. (2021). Refocusing Anggaran Di Masa Pandemi Covid-19. Conference on Economic and Business Innovation, 1(1), 774-782.

Juliasari, D., \& Rizal, N. (2021). Budget Report Analysis and Budget Realization Refocusing Covid-19. Assets: Jurnal Ilmiah Ilmu Akuntansi, Keuangan Dan Pajak, $5(1), 44-55$.

Junaidi, M., Sukarna, K., Arifin, Z., \& Soegianto, S. (2020). Kebijakan Refocusing 


\section{JOURNAL OF MANAGEMENT, ACCOUNTING, GENERAL \\ FINANCE AND INTERNATIONAL ECONOMIC ISSUES \\ (MARGINAL) \\ VOLUME 1 ISSUE 1 (2021)}

Anggaran Belanja Daerah dalam Penanganan Pandemi COVID-19. Halu Oleo Law Review, 4(2).

Karjoko, L., Handayani, I. G. A. K. R., \& Jaelani, A. K. (2020). The Problems of Controlling the Transparency of the Financial Budget Use of Corona Virus 19. Journal of Morality and Legal Culture, 1(2), 93-103.

Kartika, R. S. (2021). Kinerja ASN Dalam Menghadapi Refocusing Anggaran Di Masa Pandemi Covid-19. Jurnal Administrasi Dan Kebijakan Publik, 6(1), 20-41.

Weston, J. F., Brigham, E. F., \& KHALID, A. Q. (1994). Dasar-dasar Manejemen Keuangan, Jilid I. 